\title{
Efektivitas Biopestisida Fermentasi Daun Pepaya (Carica Papaya) untuk Mengurangi Tingkat Kerusakan Daun Tanaman Jagung Manis (Zea mays L. saccharata)
}

\author{
Ade Nur Kurniawan' ${ }^{1}$, Diah Sudiarti', Imam Bukhori Muslim ${ }^{3}$ \\ ${ }_{123}$ Pendidikan Biologi, Universitas Islam Jember \\ 1kurniawan131116@gmail.com, 2diah.sudiarti23@gmail.com, 3imambukhori916@yahoo.com
}

\begin{abstract}
ABSTRAK
Biopestisida merupakan pestisida alami yang berasal dari alam seperti daun, akar, batang dan buah. Penelitian ini tentang Efektivitas Biopestisida Tanaman Pepaya (Carica papaya) dengan Fermentasi Urine Sapi pada Tanaman Jagung Manis (Zea mays L, saccharata), yang telah dilakukan dilahan Persawahan Glagahwero Kalisat, Jl. Mayangan, Desa Glagahwero Kec. Kalisat, Kab. Jember. Penelitian ini bertujuan untuk mengetahui Efektivitas Biopestisida pada Tanaman Jagung Manis (Zea mays L. saccharata). Jenis penelitian yang digunakan adalah eksperimen. Prosedur yang digunakan adalah Rancangan Acak Langkap ( RAL ). Berdasarkan hasil penelitian efektivitas biopestisida mnggunakan fermentasi daun pepaya tidak efektif dikarenakan beberapa faktor yakni musim yang kurang tepat, lahan penanaman tidak tepat, tata letak tanaman kurang baik, hama belalang yang sulit dikendalikan.
\end{abstract}

Kata Kunci : Tanaman Papaya (Carica papaya), Tanaman Jagung Manis (Zea mays L.saccharata).

\begin{abstract}
Biopesticides are natural pesticides that come from nature such as leaves, roots, stems, and fruit. This research is about the efectiviness of papaya (Carica papaya) biopesticide with cow urine fermentation in sweet corn (Zea mays $L$. saccharata), which was conducted in Glagahwero Kalisat, Jl. Mayangan, Desa Glagahwero, Kec. Kalisat, Kab. Jember this study aims to determine the effectiviness of biopesticides on sweet corn (Zea mays L.saccharata). This type of research is experimental. The procedure used was a Completely Randomized Design (CRD). Based on the results of research, the effectiviness of biopesticides using papaya leaf fermentation is not effective due to several factors, namely the season is not right, the planting area is not right, the plant layout is not good, grasshopper pests are difficult to control.
\end{abstract}

Keywords : Plant Papaya (Carica papaya), Plant Sweet Corn (Zea mays L. saccharta)

\section{PENDAHULUAN}

\section{Latar Belakang}

Jagung manis (Zea mays L. saccharrata) adalah salah satu jenis sayuran yang disukai oleh msyarakat karena memiliki rasa yang manis dan enak serta bermanfaat bagi kesehatan, karena mengandung banyak gizi, seperti karbohidrat, protein, lemak, beberapa vitamin, dan mineral (Baihaki dkk 2020). Dalam proses produktivitas jagung manis terdapat berbagai faktor yang menjadi penentu utama keberhasilan dalam produksi jagung manis, diantaranya dari segi perlindungan tanaman, unsur hara, dan lingkungan. Dari segi perlindungan tanaman pada tanaman jagung umumnya menggunakan pestisida kimiawi, bahan dari pestisida kimiawi dapat menyebabkan residu atau bahaya pada para petani, konsumen, dan lingkungan. Peningkatan produktivitas jagung juga di pengaruhi oleh perlindungan bagi tanaman dengan tepat.Perlindungan tanaman mempunyai peranan penting 
dalam penetapan produksi pangan. Dengan teknik perlindungan tanaman yang efektif, efisien, dan tepat maka populasi hama dan penyakit dapat di kendalikan, sehingga tidak mengakibatkan kerugian bagi petani dan menjamin hasil yang optimal. Untuk menekan populasi hama ini berbagai cara pengendalian telah di tempuh baik secara kultur teknis, mekanis, biologis maupun insektisida sintetik (Pracaya, 2005). Perlindungan tanaman dilakukan dengan pestisida alami yang ramah likungan dengan cara difermentasi menggunakan urine sapi, urine sapi mengadung mikroba selolitik dan pektolitik serta mikroba pathogen yang lainnya. Kandungan pada urine sapi tersebut dapat menjadi bahan alami fermentasi dari biopestisida (Phrimantoro, 1995).

Beberapa tumbuhan diketahui memiliki kandungan zat-zat kimia yang berpotensi untuk pengendalian hama pada tanaman (Dono et al., 2013). Pemanfaatan tumbuhan sebagai bahan aktif pestisida mulai banyak digunakan untuk pengendalian hama dan penyakit. Hal ini dikarenakan tumbuhan adalah sumber bahan kimia potensial yang dapat digunakan sebagai pestisida yang ramah lingkungan dan lebih aman secara kesehatan. Di Indonesia bahan pestisida nabati banyak tersedia di alam.Sebanyak 37.000 spesies flora telah diidentifikasi dan baru sekitar 1\% yang telah dimanfaatkan (Djunaedy, 2009).

\section{METODE PENELITIAN}

Penelitian yang digunkan adalah penlitian ekperimen dengan cara observasi.

\section{a. Rancangan penelitian}

Tahap Pelaksanaan

1. Penyiapan Lahan dan Penanaman

- Lahan dibagi atas 6 bedeng
- Masing - masing bedeng di tanam benih percobaan sebanyak 10 benih

- Lakukan penyiraman 2 hari sekali pada benih percobaan

2. Aplikasi Penyemprotan

- Penyemprotan dimulai pada umur 1 minggu setelah tanam. Aplikasi penyemprotan menggunkan hand sprayer dan dilakukan pada pukul 15.00 17.00 penyemprotan dilakukan teratur 3 kali seminggu.

Tahap Pengamatan

- Dilakukan pengamatan pada tanaman usia 7 HST sampai berumur 45 - 60 hari

- Lakukan 3 kali pengulangan dalam setiap pengamatan

Pengamatan meliputi :

Pengamatan meliputi kerusakan pada daun tanaman Jagung Manis ( Zea Mays L. Saccharata )

\section{b. Metode Pengumpulan Data}

Pengumpulan data merupakan langkah yang paling strategis dalam penelitian. Pengumpulan data terdiri atas data kualitatif ( mendeskripsikan tingkat kerusakandaun pada tanaman jagung manis ) dan kuantitatif (menghitung persentase kerusakana pada tanaman ).

\section{c. Analisis Data}

Data penelitian dianalisis dengan cara deskriptif kualitatif. Untuk medeskripsikan Efektivitas Biopestisida dengan Menggunakan Fermentasi Daun Pepaya (Carica Papaya) terhadap Tingkat Kerusakan Daun pada Tanaman Jagung Manis (Zea mays L. Saccharat). 
Data kuantitatif di peroleh dengan menggunakan rumus sebagai berikut :

$\mathrm{I}=\mathrm{i} / \mathrm{N} \times 100 \%$

Keterangan :

I : Persentase daun rusak,

i : Jumlah daun rusak

N : Jumlah daun keseluruhan

\section{PEMBAHASAN}

\begin{tabular}{cc} 
Tabel. 1 Rata- rata Persentase Daun \\
Rusak \\
\hline Perlakuan & $\begin{array}{c}\text { Rata-rata } \\
\text { Persentase } \\
\text { Daun Rusak }\end{array}$ \\
& \\
\hline $100 \%$ & 6.861 \\
$75 \%$ & 6.486 \\
$50 \%$ & 9.237 \\
$25 \%$ & 5.761 \\
$\mathrm{~K}^{-}$ & 5.073 \\
$\mathrm{~K}^{+}$ & 4.750
\end{tabular}

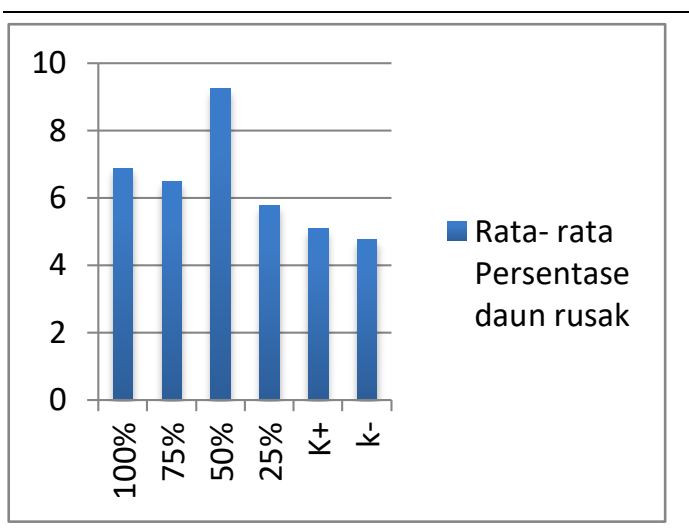

\section{Gambar 1. Diagram Batang Rata - rata Persentase Daun Rusak}

Penelitian ini bertujuan untuk menghitung kerusakan daun pada tanaman jagung manis. Berdasarkan hasil dan data dari penelitian yang dilakukan oleh peneliti diperoleh hasil yang signifikan dimana setiap perlakuan dengan konsentrasi berbeda menghasilkan persentase kerusakan daun pada tanaman jagung manis yang berbeda. Pada data yang diperoleh dan didapat bahwa tingkat kerusakan daun pada tanaman jagung manis dengan residu kerusakan daun paling rendah ada pada kontrol negatif (K-) sedangkan pada tingkat residu kerusakan daun paling tinggi terdapat pada konsentrasi 50\%, sedangkan pada tingkat konsentrasi $100 \%, 75 \%$ dan 25\% tingkat kerusakan daun jagung manis berbeda yakni 6,8\% untuk konsentrasi 100\%, 6,4 \% untuk konsentrasi $75 \%$, dan 9,2 \% untuk konsentrasi $50 \%$. Pada perlakuan $\mathrm{K}^{+}$itu menggunakan bahan kimiawi sebagai pestisidanya, tingkat kerusakan daunnya yakni 5,07\% dan $\mathrm{K}^{-}$atau kontrol negatif yang dimana bahan yang digunakan untuk biopestisida hanya air saja, tetapi $\mathrm{K}^{-}$memperoleh data yang cukup signifikan yakni menjadi dengan tingkat kerusakan yang paling rendah dengan persentase $4,7 \%$. Dari data yang di peroleh bisa dikataan bahwa efektivitas biopestisida fermentasi dari daun pepaya kurang efektif untuk mengatasi tingkat kerusakan daun pada tanaman jagung manis, tetapi bila dilihat dari 4 konsentrasi yakni 100\%, 75\%,50\%, dan $25 \%$, tingkat kerusakan yang paling rendah di dapat pada konsentrasi $75 \%$ dan $25 \%$.

Perlindungan tanaman juga banyak meliputi penggunaan bahan kimiawi yang berbahaya yang melebihi dosis, dewasa ini menimbulkan masalah cukup serius, penggunaan pestisida kimiawi tidak hanya berbahaya bagi kesehatan manusia tetapi juga berdampak pada lahan pertanian ( Sudiarti, D dan Hasbiyati, H. 2018).

Ada berbagai faktor yang menyebabkan terjadinya kerusakan daun pada tanaman jagung manis meskipun sudah di beri biopestisida diantaranya hama belalang dan cuaca yang tidak menentu. Yang menjadi peran besar pada 
tingkat keruskan daun ialah hama belalang yang sulit untuk di kendalikan. Yang menjadi faktor kerusakan daun juga musim yang tidak tepat untuk menanam jagung manis dimana peneliti menanam disaat musim kurang baik yakni memasuki musim hujan saat penyemprotan dilakukan akan sering terkena air hujan sehingga biopestisida tidak efektif, dimana tanaman jagung terlalu renta sering tergenang oleh air. Penerapan biopestisida dari fermentasi daun pepaya didapat bahwa konsentrasi yang cukup baik dalam tingkat komposisi yakni kosentrasi 75\% dan 25\% dimana tingkat konsentrasinya dapat dikatakan rendah dalam tingkat persentase daun rusak. Tingkat keursakan daun tanaman jagung manis juga dipengaruhi oleh tata letak area penanam jagung, lahan jagung manis dikeliling oleh hamparan pesawahan yang dimana lahan perswahan tersebut ditanami oleh padi yang dimana banyak mengundang hama belalang ke lahan penanam jagung manis sehingga menyebabkan kerusakan pada daun tanaman jagung manis. Dari keenam perlakuan yakni 4 konsentrasi dan 2 kontrol dapat dikatakan konsentrasi cukup efektif kosentrasi 100\% dan 75\%, sedangkan perlakuan lain ada tingkat kerusakn yang lebih rendah itupun dikarenakan dengan letak penanam yang berada di tengah area bedengan sehingga hama belalang memakan dan merusak daun yang berada dibagian paling pinggir dari lahan.

\section{KESIMPULAN}

Berdasarkan hasil dari penelitian dapat disimpulkan bahwa efektivitas biopestisida dengan menggunakan fermentasi daun pepaya dapat dikatakan kurang efektif, karena tingkat kerusakan pada daun tanaman jagung manis masih tinggi. Yang menyebabkan kurang efektifnya biopestisida dalam mengurangi tingkat keruasakan daun pada tanaman jagung manis ialah karena beberapa faktor yakni hama belalang yang sulit di kendalikan. Ini dikarena area penanam jagung manis berada di area sekeliling tanaman padi dan faktor musim yang kurang mendukung yakni penanaman jagung manis di tanam waktu memasuki musim penghujan, sehingga kurang efektifnya biopestisida sebagai pestisida alami pelindung tanaman dari kerusakan daun kurang dapat bekerja dengan baik. Dari 4 konsentrasi yakni 100\%,75\%,50\%, dan $25 \%$ racikan atau komposisi yang paling baik ada pada konsentrasi $75 \%$ dan $25 \%$ karena medapat tingkat kerusakan daun yang cukup rendah dari keempat konsentrasi.

\section{DAFTAR PUSTAKA}

Baihaki, A, Sudiarti D, Muslim I,B. 2020. “ Perbandingan Pupuk Organik Cair (POC) Gedebog Pisang (Musa paradisiaca $L$ ) dengan Pupuk Organik Cair (POC) Serabut Kelapa (Cocos muciefera L) pada Pertumbuhan Jagung Manis (Zea mays L. saccharata)" Jurnal Bioshell No. 13, 27-32 http://ejurnal.uij.ac.id/index.php/BI $\underline{\mathrm{O} / \text { article/view/752 }}$

Dono et al., (2013), Pengendalian Hama Tanaman dari Tanaman yang Berpotensi.

Djunaedy, A. (2009), Biopestisida Sebagai Pengendali Organisme Pengganggu Tanaman (OPT) yang Ramah Lingkungan.

Pracaya, (2005). Hama dan Penyakit Tanaman. Penebar Swadaya. Jakarta. 471 hlm. 
Phrimantoro.(1995), Pemanfaatan Urine Sapi Yang Difermentasi Sebagai Nutrisi Tanaman. Http:// agribisnis.deptan.go.id/Pustaka/Pen gantar/pdf.

Sudiarti, D \& Hasbiyati, H. 2018. "Peningkatan Pertumbuhan Tanaman Kedelai Edamame (Glycin max (L) merill) Melalui Pemberian Kombinasi Cendawan Mikoriza Arbuskula (CMA) dan Pupuk Kimia" Prosiding Seminar Nasional Hasil Penelitian dan Pengabdian kepada Masyarakat III. Universitas PGRI Ronggolawe Tuban. Volume 3 (2018); Hal. 449-454. (Diakses 29 September 2018) 